\title{
SISTEM PAKAR ILMU FARAIDH BERBASIS WEB DENGAN METODE FOORWARD CHAINING DAN DEPTH FIRST SEARCH
}

\author{
Ahmad Rofiq Hakim ${ }^{1)}$, Tabrani Rija' ${ }^{2}{ }^{2}$, Miftachus Sholichin ${ }^{3)}$ \\ ${ }^{1}$ Sistem Informasi, STMIK Widya Cipta Dharma \\ ${ }^{2,3}$ Teknik Informatika, STMIK Widya Cipta Dharma \\ 1,2,3 Jl. Prof. M. Yamin No. 25, Samarinda, 75123 \\ E-mail : rofiq_93@yahoo.com ${ }^{1)}$, informatikawicida@gmail.com ${ }^{2)}$, miftachus.informatika@gmail.com ${ }^{3)}$
}

\begin{abstract}
ABSTRAK
Penelitian ini dilakukan bertujuan untuk dapat membuat dan mengembangkan sebuah sistem yang interaktif, sehingga dapat membantu masyarakat muslim khususnya untuk memperoleh informasi dan memahami tentang penghitungan faraidh. Dalam penelitian ini menggunakan metode Forward Chaining dan Depth First Search. Adapun alat bantu yang digunakan antara lain Flowchart, Web Server Xamp, Database MySql, Web Developer menggunakan PHP, Editor dan Web Desain menggunakan Macromedia Dreamweaver Cs6.

Dari hasil penelitian yang diperoleh, yakni penelitian ini menghasilkan sebuah sistem pakar yang ditujukan kepada masyarakat pengguna atau yang menggunakan untuk tahu masalah faraidh dan penerpan hukum ini di kalangan masyarakat, agar tidak terjadi kesalahan baik penghitungan dan kesalah pahaman.
\end{abstract}

Kata Kunci : Sistem, Pakar, Faraidh, Web, Forward Chaining, Depth First Depth

\section{PENDAhUluan}

Sistem Pakar Ilmu Faraidh Berbasis Web dengan Metode Forward Chaining dan Depth First Search ini adalah sebuah system yang bertujuan memberikkan kemudahan kepada masyrakat untuk menghitung harta warisan berdasarkan hukum Islam,sehingga di temukan solusi keadilan dalam menentukan besaran harta yang diterima oleh setiap ahli waris sesuai dengan aturan yang telah ditentukan didalam Al-Quran sebagai pedoman dan landasan hokum agama Islam.

Banyak permasalahan yang muncul ketika adanya pembbagian warisan,karena mereka merasa kurang dan ingin menguasai harta warisan padahal masih ada saudara yang berhak mendapatkan hak untuk menerima harta waris. Hal ini di karenakan sulitnya memahami ilmu faraidh dan begitu kompleksnya perhiitungan dalam ilmu faraidh,maka dari itu di bentuk lah Sistem Pakar Ilmu Faraidh Berbasis Web dengan Metode Forward Chaining dan Depth First Search agar bisa memindahkan kepakaran seorang ahli dalam bidang Ilmu Faraidh kedalam sebuah system sehingga lebih mudah melakukan perhitungan. Dalam system ini menggunakan metode Forward Chaining dan Depth First Search karena dalam ilmu faraidh perlu adanya penelusuran antar ahli waris siapa saja yang lebih berhak dan siapa saja yang terhalang karena ada ahli waris yang lebih dekat garis keturunanya.

\section{RUANG LINGKUP PENELITIAN}

Berdasarkan uraian pada latar belakang tersebut maka permasalahan yang dapat dikemukakan adalah “ Bagaimana membuat Sistem Pakar Ilmu Faraidh berbasis Web dengan metode Forward chaining dan Depth first search “

Untuk menghindari beberapa kesalahan dalam penghitungan dan pemahaman maka diperlukan beberapa batasan masalah,yaitu:

1. Kelompok ahli waris meliputi ashabul furudh, ashabah, dzawil arham, ahli waris pengganti, dan kalalah.

2. Ilmu faraidh ini berdasarkan Mahzab Safii dan KHI (Kompilsi Hukum Islam).

3. Perancangan konseptual yang digunakan yaitu flowchart.

4. Dalam penelitian ini menggunakan Rule If - Then dengan Metode Forward chaining dan Depth first search.

\section{BAHAN DAN METODE \\ 3.1 Penjelasan Dan Bahan}

Menurut Sutabri (2005), sistem merupakan suatu bentuk integrasi antara satu komponen dengan komponen lain, karena sistem memiliki sasaran yang 
berbeda untuk setiap kasus yang terjadi yang ada didalam sistem tersebut.

Menurut Arhami (2005), pakar adalah orang yang mempunyai keahlian dalam bidang tertentu, yaitu pakar yang mempunyai knowledge atau kemampuan khusus yang orang lain tidak mengetahui atau mampu dalam bidang yang dimilikinya.

Menurut Kusrini (2008), sistem pakar adalah aplikasi berbasis komputer yang digunakan untuk menyelesaikan masalah sebagaimana yang dipikirkan oleh seorang pakar.

Ilmu Faraidh adalah ilmu yang membahas masalahmasalah pembagian harta warisan. Kata 'al-faraidh' atau yang di Indonesiakan menjadi faraidh adalah bentuk jamak dari al-faridhah yang bermakna sesuatu yang diwajibkan, artinya sesuatu pembagian yang telah ditentukan.

Ilmu faraidh meliputi beberapa bagian kepemilikan yang telah ditentukan secara tetap dan pasti. Kaidahkaidah fiqih dan cara mmenghitung untuk mengetahui bagian setiap ahli waris dari harta peninggalan. Kaidah yang berkaitan erat dengan keadaan ahli waris seperti ash-habul furudh yaitu ahli waris yang memiliki bagian yang sudah pasti, ashabah yaitu ahli waris yang menerima sisa harta peninggalan dari ash-habul furudh, dzawi al arham yaitu ahli waris yang tidak termasuk dalam ash-habul furudh dan ashabah dan hal-hal yang erat hubungnya dengan cara menyelesaikan pembagian harta berupa hijab,aul,radd, dan yang terhalang mendapatkan warisan.

Dynamic Website adalah website yang secara berkala, informasi didalamnya berubah, atau website ini bisa berhubungan dengan user dengan berbagai macam cara atau metode (HTTP cookies atau Variabel Database, sejarah kunjungan, variabel sesi dan lain-lain) bisa juga dengan cara interaksi langsung menggunakan form dan pergerakan mouse. Ketika web server menerima permintaan dari user untuk memberikan halaman tertentu, maka halaman tersebut akan secara otomatis di ambil dari media penyimpanan sebagai respon dari permintaan yang diminta oleh user. Sebuah situs dapat menampilkan dialog yang sedang berlangsung diantara dua user, memantau perubahan situasi, atau menyediakan informasi yang berkaitan dengan sang user.

Menurut Kusrini (2006), Forward chaining adalah metode runut maju berarti menggunakan himpunan aturan kondisi-aksi. Dalam metode ini, data digunakan untuk menentukan aturan mana yang akan dijalankan, kemudian aturan tersebut dijalanakan. Mungkin proses menambahkan data ke memori kerja. Proses diulang sampai ditemukan suatu hasil.

Menurut Arham(2005), Depth-first search adalah sebuah metode yang melakukan penulusuran kaidah secara mendalam dari simpul akar bergerak menurun ke tingkat dalam yang berurutan. Jadi penelusuran di lakukan secara detail dan benar-benar berurutan sampai ke akar sebuah pokok permasalahan untuk mencapai sebual goal (tujuan). Hal ini dilakukan karena semuanya segitu erat berkaitan dari simpul akar tersebut.

\subsection{Metode Air Terjun}

Menurut Sommerville (2003) model ini adalah model klasik yang bersifat sistematis, berurutan dalam membangun software. Berikut ini adalah dua gambaran dari waterfall model sekalipun keduanya menggunakan nama-nama fase yang berbeda, namun sama dalam intinya. Yang pertama adalah fase-fase dalam metode waterfall menurut referensi Pressman dan yang kedua menurut referensi Sommerville.

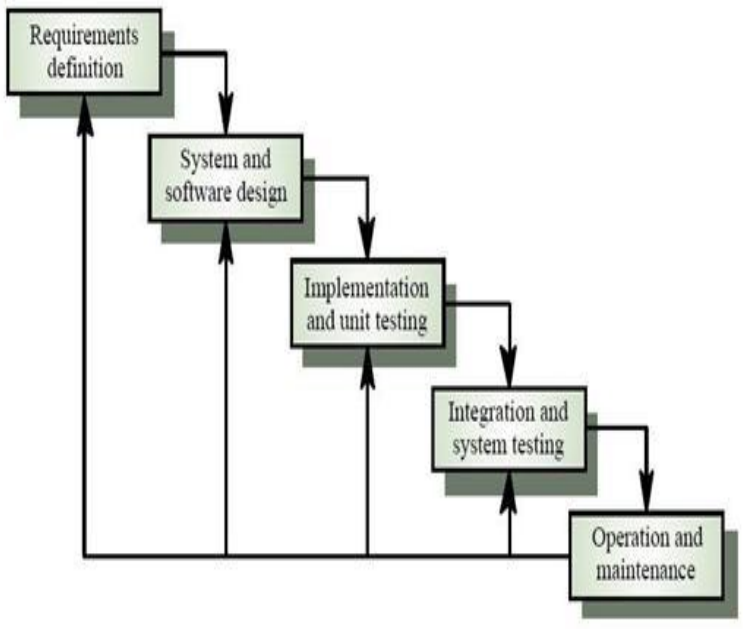

\section{Gambar 1. Metode Air Terjun}

Model air terjun (waterfall) adalah model satu arah yang dimulai dari tahap persiapan sampai perawatan, dan model inilah yang dipakai oleh penulis dalam menganalisa sistem yang akan dikerjakan (Pressman, 2002).

\section{RANCANGAN SISTEM}

Flowchart sistem menggambarkan alur dari sistem yang akan di buat, bagaimana sistem itu berjalan dari mulai sampai selesai dapat dilhat pada gambar flowchart sistem. Pada flowcahart sistem kita bisa melihat bahwa sistem akan dibuat dengan beberapa sub menu pilihan diidalam sistem, dimana untuk mmasuk kesistem sendiri dibagi menjadi dua user yaitu administrator dan common user. Dua pengguna ini mempunyai hak akses menu yang berbeda. Jika sebagai admin makam akan masuk ke menu admin dan punya 
hak akses untuk mengelola berita,konsultasi, tambah admin dan laporan. Sedangkan common user dapat menu Ilmu waris, home, pakar waris, dan contac us serta bisa mengakses beberapa berita saja,Cuma bisa mengakses dan membaca saja.

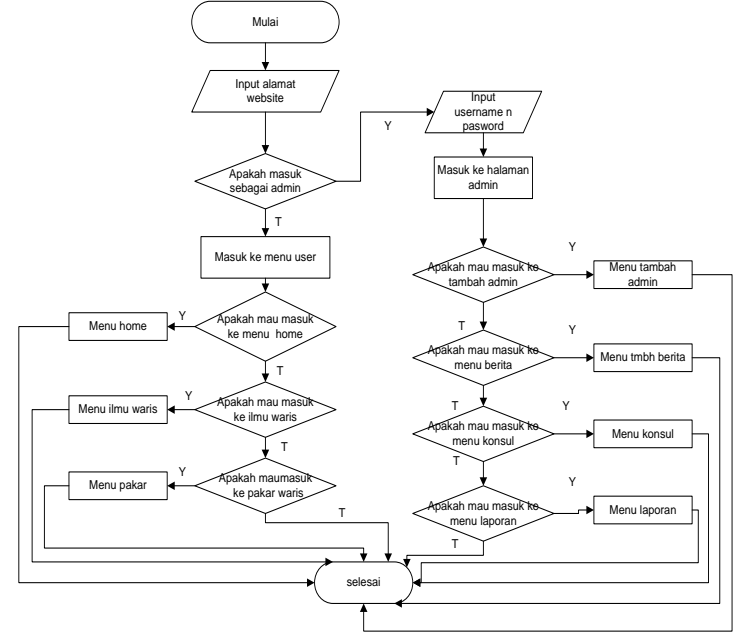

Gambar 2 flowchart sistem pakar berbasis web

2.

lowchart pakar ilmu faraidh

Flowchart ini menggambarkan alur dari pakar untukmengolah data untuk mendapat hasil dari bagian tiap ahli waris.

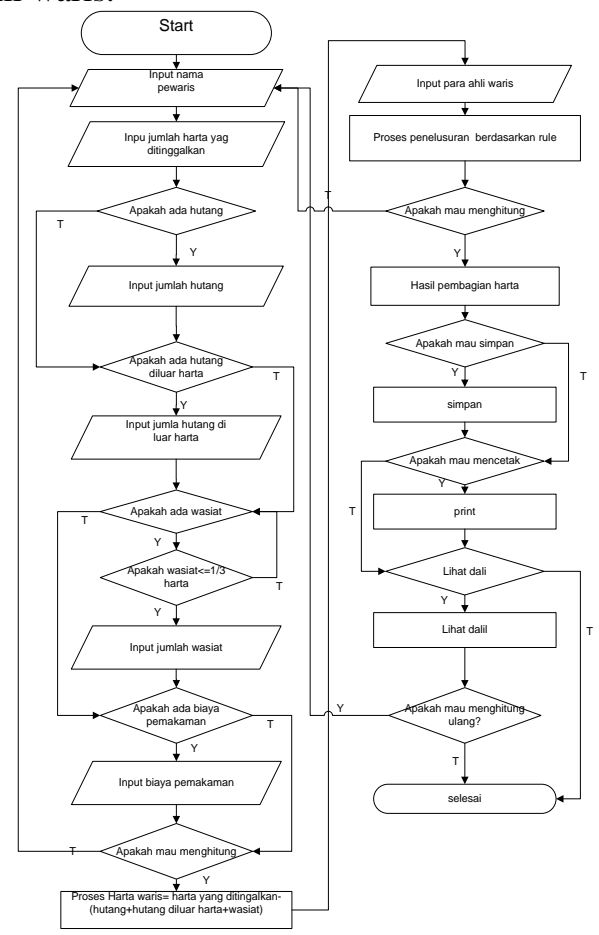

Gambar 3. flowchart pakar faraidh
3. Flowchart progam pakar

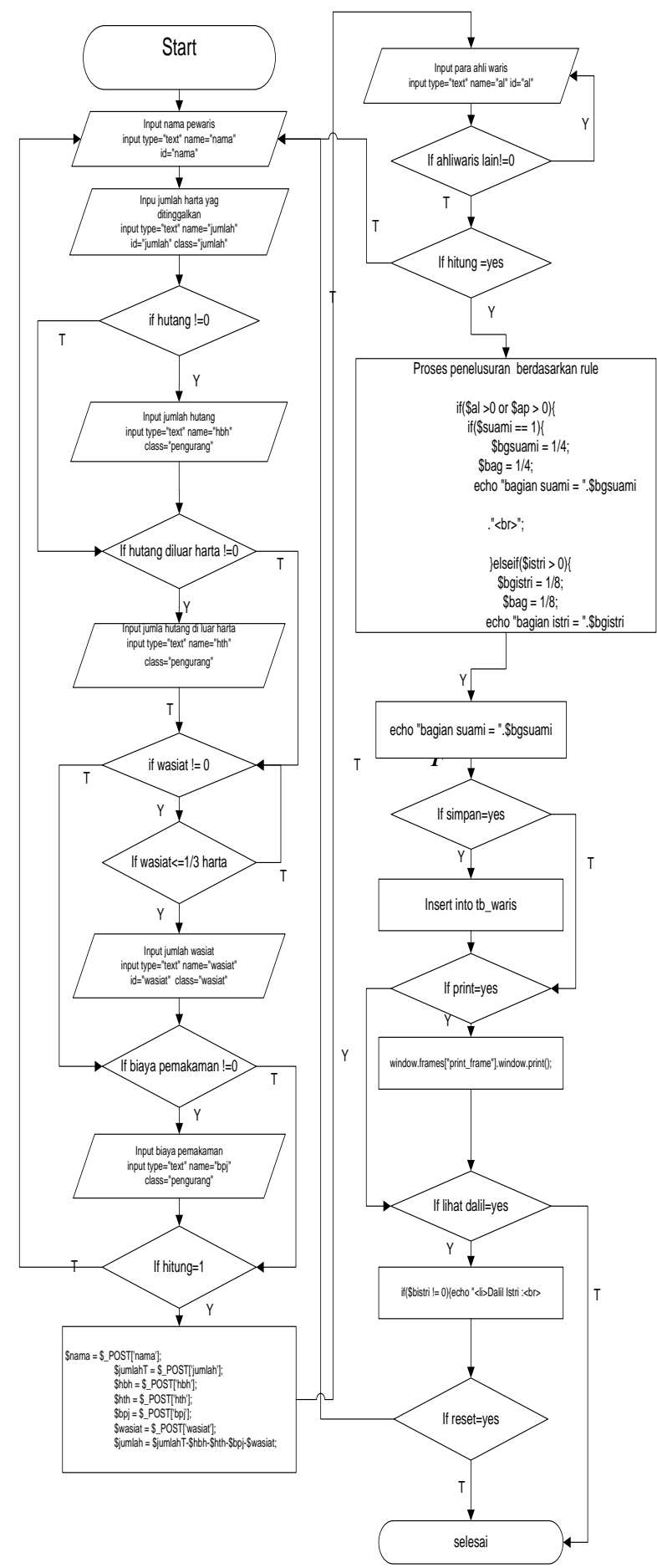

Gambar 4. flowchart progam pakar

Pada gambar 3 dan gambar 4 adalah flowchart pakar faraidh bagaimana sub kepakaran ini berjalan mulai dari awal untuk menyelesaikan harta warisan setelah di kurangi kewajiban pewaris dan pemilihan ahli waris siapa saja yang masih ada dan mengalami proses 
inferensi kedalam sebuah sistem lewat forward chaining dan depth first search sehingga mendapatkan hasil yaitu bagian masing-masing dari ahli waris. Proses inferennsi dalam depth first search dapat dilihat pada gambar 5 .

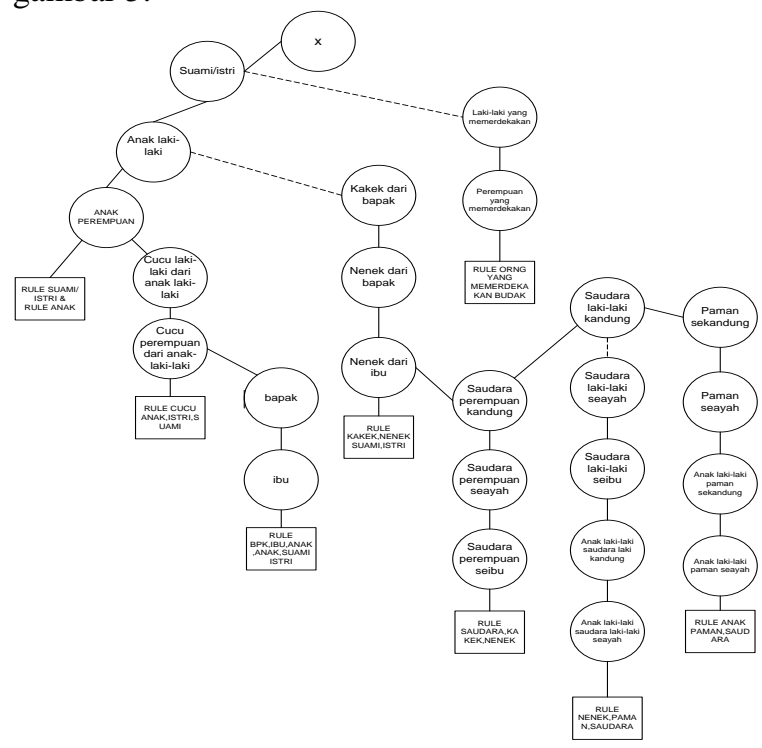

Gambar 5. Tree Depth First Search ilmu faraidh

Pada algoritma DFS diatas pencarian dilakukan pada satu node dalam setiap level dari yang paling kiri. Dari node kiri terus kekanan,untuk menelusuri ahli waris yang ada, jika yang ada sudah di telusuri semua maka hanya ahli waaris yang berhasil ditelusuri saja yang akan di simpan di memori.

Tabel 1. Tabel pembagian harta waris

\begin{tabular}{|c|c|c|c|}
\hline No & Nama ahli waris & Bagian & Ketentuan \\
\hline & Anak & & \\
\hline 1. & $\begin{array}{l}\text { Satu orang anak } \\
\text { laki-laki atau lebih }\end{array}$ & $\begin{array}{l}\text { Ashobah } \\
\text { bin nafsi }\end{array}$ & $\begin{array}{l}\text { Tidak terhalang } \\
\text { siapapun }\end{array}$ \\
\hline 2. & Anak perempuan & $\begin{array}{l}\text { Ashobah bil } \\
\text { ghoir }\end{array}$ & $\begin{array}{l}\text { Jika ada anak laki- } \\
\text { laki }\end{array}$ \\
\hline 3. & $\begin{array}{l}\text { Satu anak } \\
\text { perempuan }\end{array}$ & $1 / 2$ & $\begin{array}{l}\text { Jika tidak ada } \\
\text { anak laki-laki }\end{array}$ \\
\hline \multirow[t]{2}{*}{4.} & $\begin{array}{lr}\text { Anak } & \text { perempuan } \\
\text { lebih dari satu } \\
\text { orang }\end{array}$ & $2 / 3$ & $\begin{array}{l}\text { Jika tidak ada } \\
\text { anak laki-laki }\end{array}$ \\
\hline & cucu & $\begin{array}{l}\text { Terhalang } \\
\text { atau } \\
\text { mahjub }\end{array}$ & $\begin{array}{l}\text { Jika masih ada } \\
\text { anak laki-laki }\end{array}$ \\
\hline 1. & $\begin{array}{ll}\text { Satu orang } & \text { cucu } \\
& \\
\text { perempuan } & \text { atau }\end{array}$ & $\begin{array}{l}\text { Ashobah bil } \\
\text { ghoir }\end{array}$ & $\begin{array}{l}\text { Jika bersama cucu } \\
\text { laki-laki }\end{array}$ \\
\hline
\end{tabular}

\begin{tabular}{|c|c|c|c|}
\hline & lebih & & \\
\hline 2. & $\begin{array}{l}\text { Satu orang cucu } \\
\text { perempuan dari anak } \\
\text { laki-lai }\end{array}$ & $1 / 2$ & $\begin{array}{l}\text { Jika tidak ada } \\
\text { cucu laki-laki }\end{array}$ \\
\hline 3. & $\begin{array}{l}\text { Dua atau lebih cucu } \\
\text { perempuan dari anak } \\
\text { laki-laki }\end{array}$ & $2 / 3$ & $\begin{array}{l}\text { Jika tidak ada } \\
\text { anak perempuan } \\
\text { atau } \\
\text { perempuan dari } \\
\text { anak laki-laki }\end{array}$ \\
\hline 4. & $\begin{array}{c}\text { Satu orang cucu } \\
\text { perempu } \\
\text { an atau } \\
\text { lebih }\end{array}$ & $1 / 6$ & $\begin{array}{lr}\text { Jika ada } & \text { satu } \\
\text { orang } & \text { anak } \\
\text { perempuan, } & \text { tetapi } \\
\text { jika } & \text { anak } \\
\text { perempuan } & \text { lebih } \\
\text { dari satu } & \text { orang } \\
\text { maka } & \text { cucu } \\
\text { mahjub } & \end{array}$ \\
\hline & Ayah atau ibu & & \\
\hline \multirow[t]{2}{*}{1.} & \multirow[t]{2}{*}{ Ayah } & $\begin{array}{l}\text { Ashabah } \\
\text { bin nafsi }\end{array}$ & $\begin{array}{llr}\text { Jika } & \text { tidak } & \text { ada } \\
\text { anak laki } & \text {-laki } \\
\text { atau cucu laki-laki } \\
\text { dari anak laki-laki }\end{array}$ \\
\hline & & $1 / 6$ & $\begin{array}{l}\text { Jika ada anak laki- } \\
\text { laki atau cucu laki } \\
\text { laki dari anak } \\
\text { laki-laki }\end{array}$ \\
\hline \multirow[t]{2}{*}{2.} & \multirow[t]{2}{*}{ ibu } & $1 / 3$ & $\begin{array}{l}\text { Jika tidak ada } \\
\text { anak atau cucu }\end{array}$ \\
\hline & & $1 / 6$ & $\begin{array}{l}\text { Jika ada anak atau } \\
\text { cucu atau dua } \\
\text { orang atau lebih } \\
\text { saudara laki-laki } \\
\text { atau perempuan }\end{array}$ \\
\hline No & Nama ahli waris & Bagian & Ketentuan \\
\hline \multirow[t]{3}{*}{1.} & \multirow[t]{3}{*}{ kakek } & $\begin{array}{l}\text { Ashabah } \\
\text { bin nafsi }\end{array}$ & $\begin{array}{l}\text { Jika tidak ada } \\
\text { anank laki-laki } \\
\text { atau cucu laki-laki } \\
\text { dari anak laki-laki }\end{array}$ \\
\hline & & $1 / 6$ & $\begin{array}{l}\text { Jika tidak ada } \\
\text { ayah atau cucu } \\
\text { laki-laki dari anak } \\
\text { laki-laki }\end{array}$ \\
\hline & & $\begin{array}{l}\text { Terhalang / } \\
\text { mahjub }\end{array}$ & $\begin{array}{l}\text { Jika masih ada } \\
\text { anak atau ayah }\end{array}$ \\
\hline
\end{tabular}




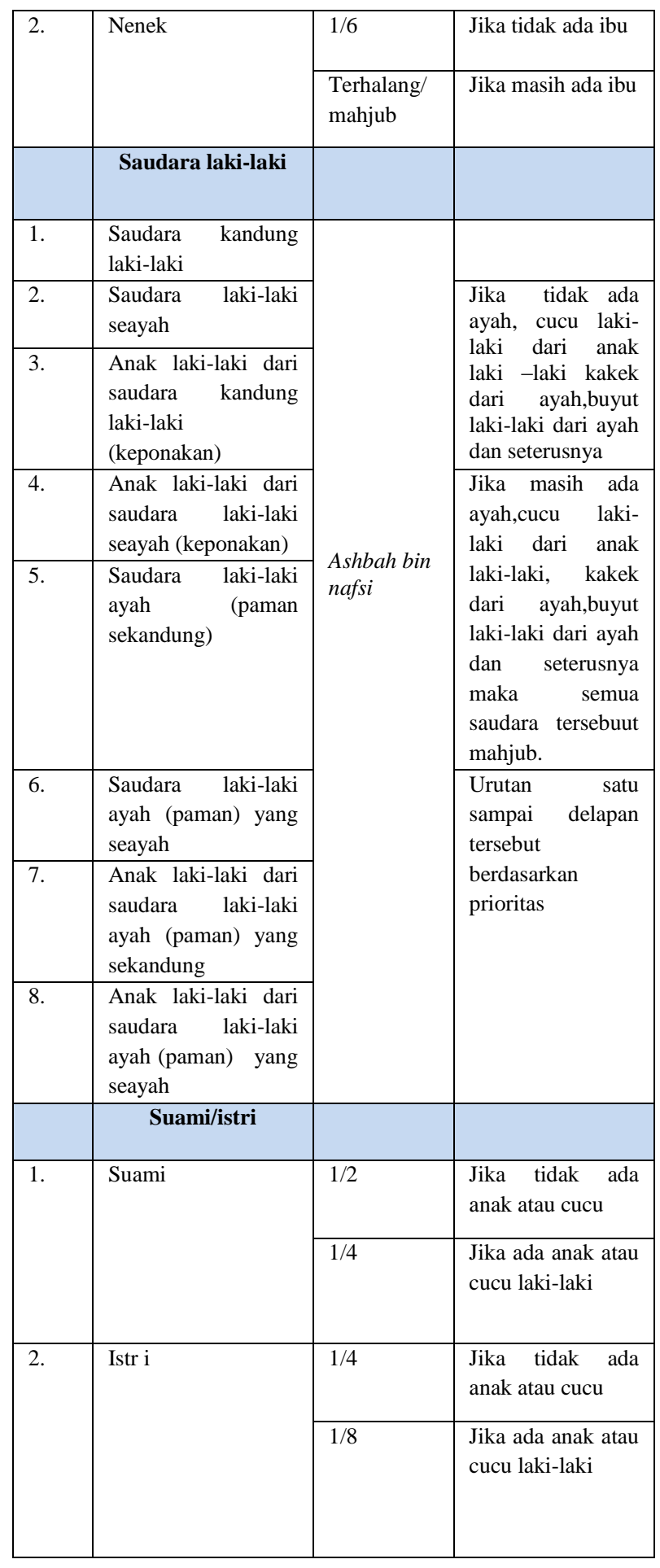

\begin{tabular}{|l|l|l|l|}
\hline No & Nama ahli waris & Bagian & Ketentuan \\
\hline & $\begin{array}{l}\text { Saudara } \\
\text { perempuan }\end{array}$ & & \\
\hline
\end{tabular}

\begin{tabular}{|l|l|l|l|}
\hline 1. & $\begin{array}{l}\text { Satu orang } \\
\text { saudara kandung } \\
\text { perempuan }\end{array}$ & $1 / 2$ & $\begin{array}{l}\text { Jika tidak ada } \\
\text { anak laki-laki } \\
\text { atau cucu laki- } \\
\text { laki dari anak } \\
\text { laki-laki }\end{array}$ \\
\cline { 3 - 4 } & $\begin{array}{l}\text { Ashabah } \\
\text { maal } \\
\text { ghoir }\end{array}$ & $\begin{array}{l}\text { Jika bersama } \\
\text { anak } \\
\text { perempuan } \\
\text { atau cucu } \\
\text { perempuan dari } \\
\text { anak laki-laki }\end{array}$ \\
\hline
\end{tabular}

\section{Struktur database}

\section{Tabel Waris}

Tabel

Kunci Utama

Keterangan

: tb_waris

: id

: tabel yang berisi perhitungan

Tabel 1 Struktur Tabel Waris

\begin{tabular}{|l|l|l|l|l|}
\hline No & Nama & Data type & Size & \multicolumn{2}{|c|}{ Keterangan } \\
\hline 1 & Id & Integer & 11 & $\begin{array}{l}\text { No } \\
\text { menggunakan sistem } \\
\text { pakar }\end{array}$ \\
\hline 2 & Nama & Varchar & 150 & Nama mayit \\
\hline 3 & Jb & Varchar & 20 & $\begin{array}{l}\text { Jumlah harta yang } \\
\text { dibagikan }\end{array}$ \\
\hline 4 & Aw & Varchar & 255 & Ahli waris \\
\hline 5 & Jum & Varchar & 255 & $\begin{array}{l}\text { Jumlah bagian ahli } \\
\text { waris }\end{array}$ \\
\hline 6 & Tgl & Varchar & 50 & $\begin{array}{l}\text { Tgl menggunakan } \\
\text { sistem pakar }\end{array}$ \\
\hline 7 & jam & Varchar & 25 & $\begin{array}{l}\text { Jam mengakses } \\
\text { sistem pakar }\end{array}$ \\
\hline
\end{tabular}

2. Tabel Berita

Tabel

Kunci utama

: tb_berita

Keterangan

: id

: tabel berisi berita yang kita masukkan ke web

Tabel 2 Struktur Tabel Berita

\begin{tabular}{|l|l|l|l|l|}
\hline No & \multicolumn{1}{|c|}{ Nama } & Data type & \multicolumn{1}{c|}{ Size } & \multicolumn{1}{|c|}{ Keterangan } \\
\hline 1 & ID & Integer & 11 & Id penginputan berita \\
\hline 2 & Judul & Varchar & 225 & Judul dari berita \\
\hline 3 & Isi & Text & & Isi berita \\
\hline 4 & Gambar & Varchar & 100 & Gambar dari berita \\
\hline 5 & Tanggal & Varchar & 50 & $\begin{array}{l}\text { Tangal pembuatan } \\
\text { berita }\end{array}$ \\
\hline
\end{tabular}

Tabel berita berisi berita-berita yang administrator upload ke dalam sistem,dimana bisa memberikan informasi yang berhubungan dengan sistem. Mulai dari hal-hal yang berhubungan dengan keilmuan faraidh maupun mengenai berita keislaman dan perkembanganya. 
4. Tabel konsul

Tabel

Kunci Utama

Keterangan

: tb_konsul

$:$ id

: tabel berisi konsultasi para

user yang di kirim ke sistem guna mendapat jawaban dari admin.

Tabel 3 Struktur Tabel konsul

\begin{tabular}{|l|l|l|l|l|}
\hline No & Nama & Data type & Size & \multicolumn{1}{|c|}{ Keterangan } \\
\hline 1 & Id & int & 11 & Id konsultasi dikiirim \\
\hline 2 & Dari & Varchar & 150 & Identitas pengirim konsul \\
\hline 3 & Masalah & Text & 150 & $\begin{array}{l}\text { Permasalahan yang di } \\
\text { konsultasikan }\end{array}$ \\
\hline 4 & Tgl & Varchar & 25 & $\begin{array}{l}\text { Tanggal pengiriman } \\
\text { konsultasi masalah }\end{array}$ \\
\hline 5 & Status & Varchar & 10 & $\begin{array}{l}\text { Status dari man dangapi } \\
\text { apakah sudah di tanga }\end{array}$ \\
\hline
\end{tabular}

\section{Tabel Pakar}

$\begin{array}{ll}\text { Tabel } & \text { : tb_pakar } \\ \text { Kunci utama } & \text { : id }\end{array}$

Keterangan :tabel berisi nama-nama user,dimana disini user yang terdaftar adalah user dalam kategori administrasi dan sederajatnya,yang berfungsi untuk melkaukan pengolahan dan pemeliharaan sistem.

Tabel 4 Struktur tabel pakar

\begin{tabular}{|l|l|l|l|l|}
\hline No & \multicolumn{1}{|c|}{ Nama } & Data type & Size & \multicolumn{1}{|c|}{ Keterangan } \\
\hline 1 & id & Integer & 11 & No urut user \\
\hline 2 & username & Varchar & 50 & Nama user \\
\hline 3 & password & Varchar & 32 & $\begin{array}{l}\text { Password untuk } \\
\text { masuk ke menu }\end{array}$ \\
\hline
\end{tabular}

\section{Tabel statistik}

Tabel

: tb_statistik

Kunci utama : id

Keterangan :tabel berisi jumlah pengunjung sistem ini.

Tabel 5 Struktur tabel statistik

\begin{tabular}{|l|l|l|l|l|}
\hline No & Nama & Data type & Size & Keterangan \\
\hline 1 & Ip & Varchar & 20 & $\begin{array}{l}\text { Ip user yang mengunjungi } \\
\text { sistem }\end{array}$ \\
\hline 2 & Tgl & Date & & Taanggal akses \\
\hline 3 & Hits & Int & 11 & $\begin{array}{l}\text { Jumlah user meng-klik } \\
\text { sistem }\end{array}$ \\
\hline 4 & Online & Int & 11 & \\
\hline
\end{tabular}

\section{IMPLEMENTASI}

Berikut dijabarkan hasil dari implementasi dari sistem

\subsection{Tampilan menu utama pada progam}

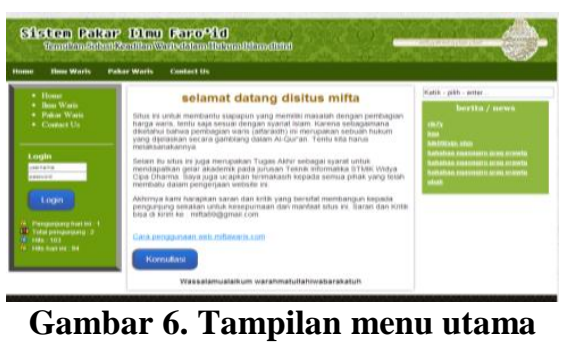

Pada gambar 6 diatas adalah tampilan menu utama dari sistem pakar ilmu faraidh. Didalam sistem ini ada beberapa sub menu yang dapat di akses,yaitu home,ilmu waris,pakar waris dan contac us, ada beberapa tombol yaitu login,konsultasi dan search berita atau artikel.

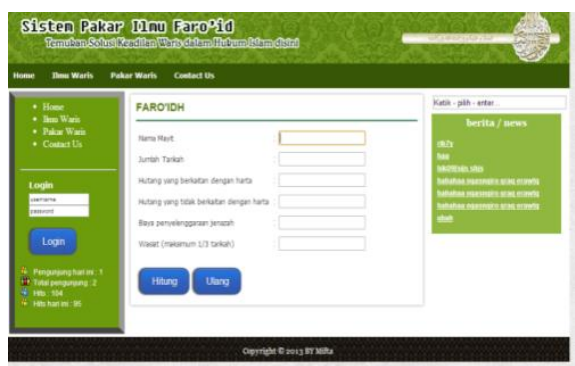

Gambar 7. Tampilan pakar waris

\subsection{Tampilan form pakar waris}

Pada gambar 7 diatas merupakan form pakar waris,dimana jika kita akan menghitung waris maka harus diisi form tersebut untuk menghitung harta waris yang mau dibagi setelah dikurangi kewajiban mayit.

\subsection{Halaman untuk inpuk ahli waris}

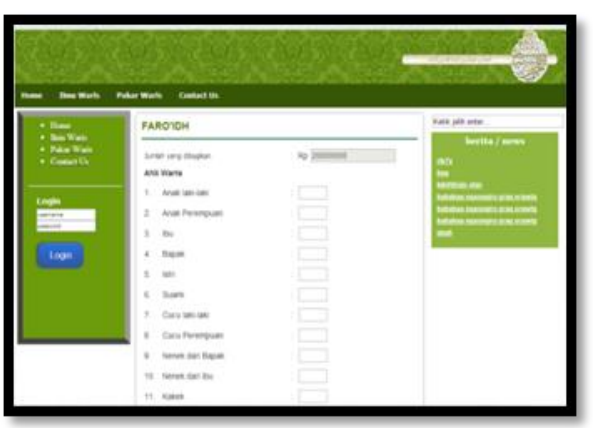

Gambar 8. Tampilan input ahli waris yang ditinggalkan 
Pada gambar 8 diatas merupakan gambar tampilan menu untuk input ahli waris yang ditinggalkan. Macam dari ahli waris ada 25 (dua puluh lima) ahli waris. Inputkan ahli waris siapa saja yang masih ada,maka sistem akan secara otomatis menyeleksi ahli waris mana saja yang berhak mendapat harta warisan dan ahli waris mana yang tidak mendapatkan harta waris,hal ini terjadi berdasarkan rule yang sudah di masukkan. Tampilan hasil perhitungan bisa dilihat pada gambar 9 di bawah ini.

\subsection{Halaman hasil hitung waris}

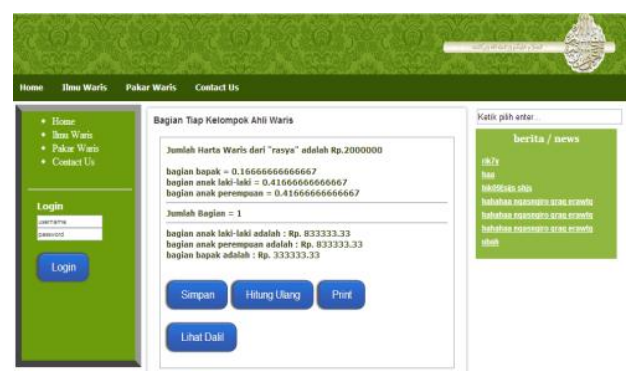

Gambar 9. Gambar tampilan hasil penghitungan waris

Pada gambar 9 diatas dapat dilihat hasil dari penghitungan harta waris berapa bagian dari masingmasing ahli waris yang dinputkan,hasil berupa baian ahli waris berupa hitungan bilngan dan hitungan secara nominal dari besaran harta yang dibagikan. Pada form diatas ada tombol print,simpan,hitung ulang dan lihat dalil.

Ketika di klik simpan maka perhitungan akan tersimpan dalam data base. Jika di klik tombol hitung ulang maka akan kembali ke menu pakar utama dan memasukkan perhitungan dari awal seperti pada gambar 9 dan jika di klik tombol lihat dalil maka akan menampilkan dalil dari hasil pembagian apakah sesuai dengan yang ada dalam alquran apa tidak. Hal ini bisa dilihat pada gambar 10 berikut.

\subsection{Halaman dalil}

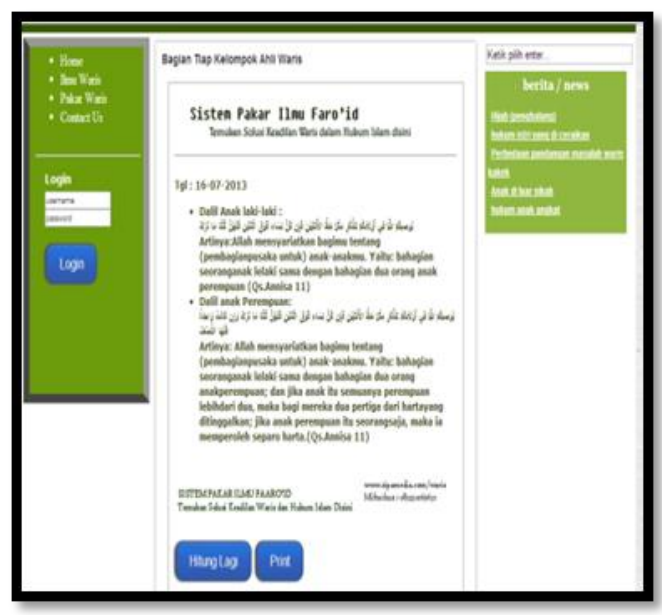

Gambar 10. Tampilan form dalil

Gambar diatas menunjukan jika kita klik tombol dalil dan melihat hasilnya. Apabila kita akan mencetak hasil dari perhitungan maka hasilnya akan tampak seperti pada gambar 11 Hasil dari perhitungan akan dicetak sesuai hasil sitem,dan akan ada tanggal waktu user mengakses sistem tersebut. Keakuratan bisa di pertanggung jawabkan karena hasil dan dalil samasama bisa di cetak untuk cros cek dari hasil penghitungan.

Sisten Pakar Ilnu Faro'id

Temuban Solusi Keadilien Worris dilam Hutum Iliam dicial

Tgl: 03-07-2013
Jumbh hara nereu yang akan dhagkan adabh Rp. $8.0 \mathrm{E}+19$

Jumbh pembagin FAROIDH : 1.16666666667

Hak sumi 0.5 dari total harta

Hak bu: 0.3333333333333

Hak bapak :0.333333333333 dari iotal harta

Total penbagin FARO'IDH scbesar 1.16666666667, schingg kbih dari I (Auf) maka akan dhining seperti berikut :

suemi dari $1 / 4$ merijadi $5 / 27$, bu dari 1/6 menjadi $3 / 27$, ank perempuan dari $2 / 3$ menjadi $16 / 27$ dan bapak dari $1 / 6+$ 'as merijadi $3 / 2$ ?

Hak sami : 0.185185185185 atau Rp.1.48148148148E+19

Hak bu :0.111111111111 atau Rp.8.88888888899E+18

Hakk ank perempun : 0 atau Rp.4.74074074074E +19

Hak bapak : 0 atau Rp.8.88888888889E +18

Gambar 11. Print preview cetak hasil penghitungan 


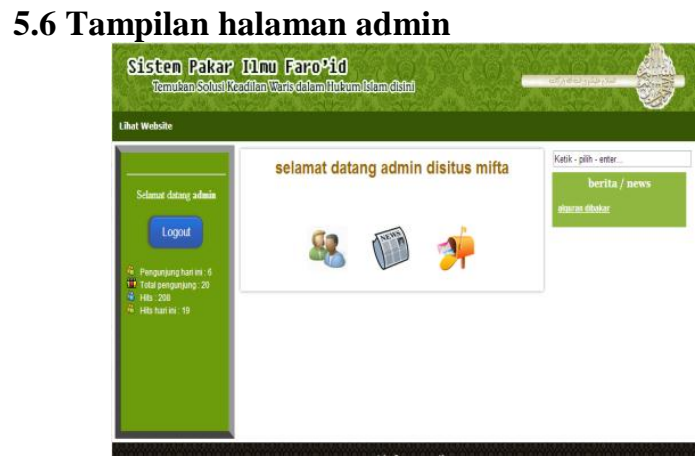

Gambar 12. Tampilan halaman admin

Pada gambar 12 dapat dilihat admin bisa masuk dan bisa melakukan hak akses berupa tambah pengguna,tambah berita dan merespon konsultasi dari user.

\subsection{Tampilan form berita}

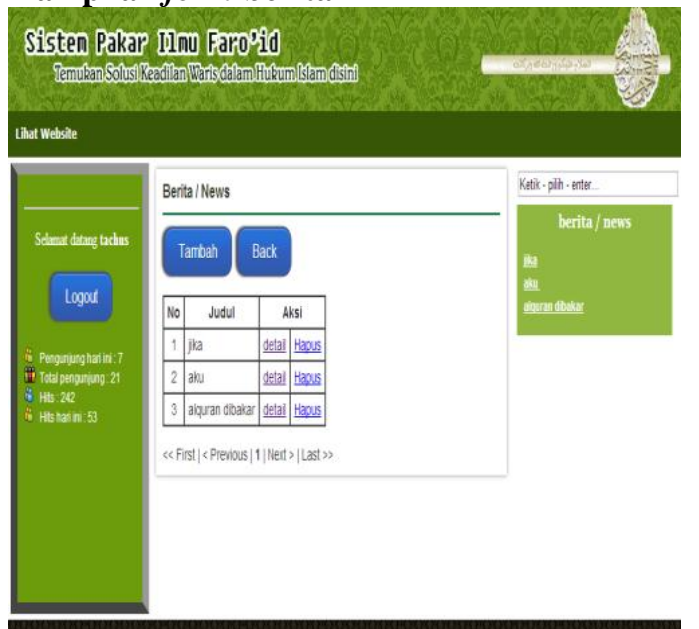

Gambar 13. Form tampilan isi berita

Pada form ini admin bisa menmbahkan berita,mulai dari edit,hapus dan menambahkan berita untuk di posting ke halaman web. Tampilan interface muka akan berisi maksimal 10 (sepuluh) berita,jika lebih maka akan tampil di halaman berikutnya.

\subsection{Tampilan form konsultasi}

Pada tampilan form konsultasi administrator bisa melihat daftar konsultasi dari user yang mengirimkan saran dan konsultasinya.. Adminiistrator bisa menandai apakah keluhan dari user sudah di tanggapi apa belum dengan menglik tombol tandai, maka aka berubah menjadi sudah atau belum. Respon darikeluhan ini bisa di tampilkan di berita melalui tambah berita atau melaui perbaikan progam. Tampilan konsultasi biisa dilihat pada gambar 14 berikut.

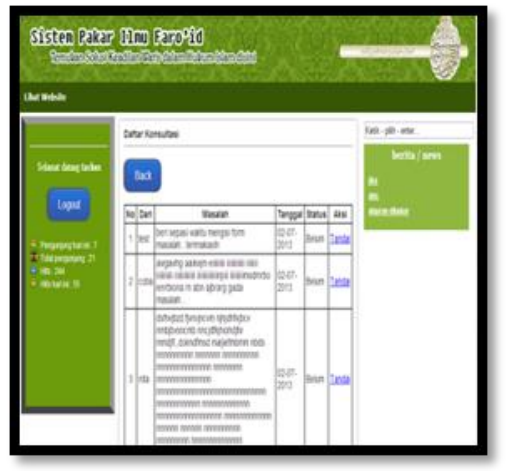

Gambar 14. Tampilan form konsultasi dari user.

\section{KESIMPULAN}

Dari hasil penelitian dan pembahasan yang dilakukan, maka dapat ditarik kesimpulan sebagai berikut :

1. Untuk membuat Sistem Pakar Ilmu Faraidh berbasis Web dengan Metode Forward Chaining dan Depth First Search diperlukan seorang pakar di bidang ilmu faraidh dan beberapa referensi keilmuan islam, dan bahasa pemrograman HTML,PHP, dan kemudian melalui tahapan analisa, desain dan implementasi.

2. Sistem Pakar Ilmu Faraidh berbasis Web dengan Metode Forward Chaining dan Depth First Search dapat membantu bagi setiap muslim yang ingin mengetahui segala hal mengenai ilmu faraidh dan penjelasan seputar ilmu faraidh. Penghitungan harta waris yang begitu kompleksnya bisa sangat mudah di akses melalui sistem ini. Sehingga hukum Islam bisa diterapkan di kalangan umat Islam dimana di dalam perkembanganya semakin terlupakan oleh hukum-hukum barat yang lebih condong bertolak belakang dengan hukum Islam.

3. Kelebihan Sistem Pakar Ilmu Faraidh ini selain hasil yang di peroleh juga bisa dilhat dalil-dalil yang mendasari seorang ahli waris mendapatkan bagian yang sesuai dengan perhitungan,dimana dalil-dalil itu berdasarkan Al-quran yang bisa di tampilkan dalam setiap penghitungan.

4. Kekurangan dari Sistem Pakar Ilmu Faraidh ini masih belum membahas perhitungan berdasarkan semua Mahzab yang ada didalam hukum Islam, karena ada beberapa perbedaan di beberapa Mahzab yang ada. 


\section{SARAN}

Adapun saran yang dapat penulis sampaikan:

1. Sistem Pakar Ilmu Faraidh berbasis Web dengan Metode Forward Chaining dan Depth First Search ini dijadikan sebagai acuan atau referensi bagi mahasiswa bidang informatika.

2. Sistem Pakar Ilmu Faraidh berbasis Web dengan Metode Forward Chaining dan Depth First Search ini dapat dikembangkan lebih lanjut, dengan menambahkan beberapa perhitungan dengan beberapa mahzab islam,seperti Hannafi,Maliki,dan Mahzab hambali.

\section{DAFTAR PUSTAKA}

Arhami, 2005, Konsep Dasar Sistem Pakar, Yogyakarta: Penerbit Andi

Hasan,A. 2003, AL-Fara'id Ilmu Pembagian Waris, Surabaya: Pustaka Progesif.

Kadir, Abdul. 2010, Panduan Menyusun Laporan Tugas Akhir,Skripsi,Dan Tesis Menggunakan Microsoft Word, Yokyakarta: Penerbit MediaKom.

Kadir,Abdul. 2003, Pemograman Web mencangkup: Html,CSS,Javascript, dan PHP ,Yogyakarta:Penerbit Andi.

Peranginangin,Kasiman. 2006, Aplikasi web dengan PHP dan MySQL, Yogyakarta: Penerbit Andi.

Komputer, Wahana. 2010, Panduan belajar MySql Database Server, Jakarata: PenerbitMedia kita.

Kusrini. 2006, Sistem pakar teori dan aplikasi, Yokyakarta:Penerbit Andi.

Lusiana,Elvi. 2011, Cara mudah \&benar Membagi harta waris,Jakarta: Penerbit Qultum media.

Mediakom, Redaksi. 2012, Progam Kasir Retail Siap Pakai Update, Yokyakarta: Penerbit MediaKom.

Nugroho,Bunafit. 2012, Panduan Proyek Sistem penjualan Retail Mini Market berbasis multi User dengan Visual Basic 6 dan MySQL, Yokyakarta : Mediakom.

Pressman, Roger. S, 2002, Rekayasa Perangkat Lunak, Yogyakarta:Andi Offset
Rindya,Dhanny. 2010, Aplikasi Perhitungan waris berorientasi objek menggunakan java,Samarinda: Polnes Samarinda. 